\title{
MODELS OF CURRENCY CRISES WITH SELF-FULFILLING FEATURES
}

Maurice Obstfeld

Working Paper 5285

\author{
NATIONAL BUREAU OF ECONOMIC RESEARCH \\ 1050 Massachusetts Avenue \\ Cambridge, MA 02138 \\ October 1995
}

This paper was prepared for the European Economic Association tenth annual congress, Prague, Czech Republic, September 1-4, 1995. Matthew T. Jones provided excellent research assistance. Financial support from the National Science Foundation of the United States, the Ford Foundation, and the Center for German and European Studies at the University of California, Berkeley, is acknowledged with thanks. This paper is part of NBER's research programs in International Finance and Macroeconomics, and International Trade and Investment. Any opinions expressed are those of the author and not those of the National Bureau of Economic Research.

(C) 1995 by Maurice Obstfeld. All rights reserved. Short sections of text, not to exceed two paragraphs, may be quoted without explicit permission provided that full credit, including $\odot$ notice, is given to the source. 


\title{
MODELS OF CURRENCY CRISES WITH SELF-FULFILLING FEATURES
}

\begin{abstract}
The discomfort a government suffers from speculation against its currency determines the strategic incentives of speculators and the scope for multiple currency-market equilibria. After describing an illustrative model in which high unemployment may cause an exchange-rate crisis with self-fulfilling features, the paper reviews some other self-reinforcing mechanisms. Recent econometric evidence seems to support the practical importance of these mechanisms.
\end{abstract}

Maurice Obstfeld

Department of Economics

University of California

Berkeley, CA 94720

and NBER 


\section{Introduction}

After more than a year of high tension in markets for European Monetary System (EMS) currencies, member countries agreed in August 1993 to widen the fluctuation bands for most Exchange Rate Mechanism (ERM) rates from \pm 2.25 percent around par to \pm 15 percent. What is remarkable about subsequent ERM experience is the bark in the night that was not heard: by August 1995, the French franc, Belgian franc, and Danish krone, all of which came under intense speculative attack in 1992-93, were not far from the lower edges of the original ERM bands that had been widened two years previously. The greater exchange-rate flexibility conferred by the broad bands, while tactically convenient for policy on occasion, did not lead to substantial currency depreciation. Figure 1 shows the evolution of the three currencies' prices in terms of deutschemarks, together with the pre- and post-August 1992 ERM fluctuation bands.

While Europe has moved into recovery, much of fundamental, long-term importance has not changed for the countries in figure 1 since August 1993: all three countries' unemployment rates remain in double digits, Belgium's public debt still exceeds its annual GDP. Thus, the exchange-rate record throws prima facie doubt on the applicability to these countries of classical theories of rational speculative 


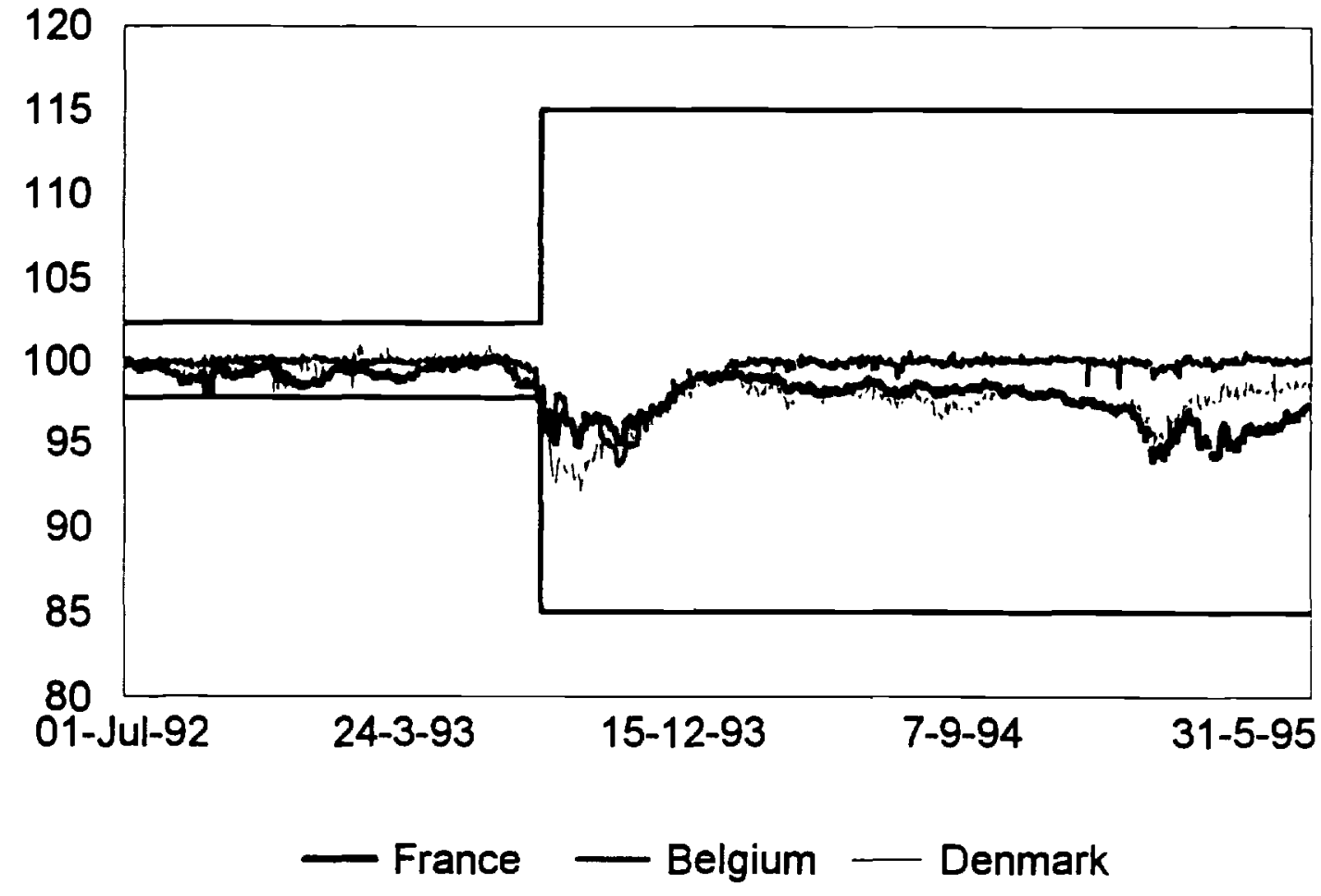

Figure 1: Daily exchange rates against the DM (index), July 1993-July 1995. Source: IMF, International Financial Statistics. 
attack, such as those of Krugman (1979) and Flood and Garber (1984), in which a fixed exchange rate contains inflationary pressures which ultimately explode in a sudden balance-of-payments crisis that frees the currency to depreciate. At the time speculators attacked, none of the three exchange rates in figure 1 was unsustainable in the sense the classical crisis models postulate.

A newer generation of crisis models suggests that even sustainable currency pegs may be attacked and even broken. The focus is on the government's continuous comparison of the net benefits from changing the exchange rate versus defending it. These models appear to give a more accurate portrayal of the recent EMS crisis and of aspects of other crises, such as Mexico's in 1994-95. The brief space available here allows only selective coverage of recent thinking on currency crises. Readers who want more should consult Calvo (1995), Jeanne (1995a), and Obstfeld (1994) for theoretical surveys, and Eichengreen and Wyplosz (1993) for detailed discussion of individual countries' positions at the onset of the EMS crisis.

\section{Strategic foundations}

Like a run on a bank, speculation against a currency creates objective economic conditions that make liability devaluation more likely. As a result, even pegged exchange rates that could be sustained indefinitely in the absence of a specu- 
lative attack can succumb to adverse market sentiment. Underlying macroeconomic 'fundamentals' are far from irrelevant to the outcome, however, for they determine the range of possible equilibria. A simple prototype model illustrates how the coordination problem of currency-market traders changes when changing macroeconomic fundamentals alter the degree of discomfort a government will suffer because of an attack.

The prototype model contains three agents, a government that sells foreign reserves to fix its currency's exchange rate and two private holders of domestic currency who can continue holding it or sell it to the government for foreign currency. Ultimately one wishes to model an economy with many competitive money holders, but the two-trader paradigm captures important features of more realistic cases. ${ }^{1}$

The government commits a finite stock of reserves, $R$, to defend the currency peg. This assumption need not reflect an inelastic lower limit to reserve holdings; more realistically, alternative reserve 'limits' reflect differing degrees of commitment to the exchange rate's defense. The tenacity with which the exchange rate is defended can depend on a variety of developments in the domestic economy, as in the fully-articulated models to be reviewed below. For now the government's

\footnotetext{
${ }^{1}$ Chen (1995) presents an explicitly strategic, dynamic analysis.
} 
payoffs are not modeled explicitly.

The size of the committed reserve stock defines the payoffs in the one-shot noncooperative game that the two private traders play. A first game, shown in normal form in figure 2a, is the High Reserve game. Committed government reserves, $R$, are 20 and each trader has domestic money resources of 6 which can be sold to the government for reserves ('Sell'), or held ('Hold'). (Think of these resources as a measure of the strength of market opinion.) To sell and take a position against the current rate, traders bear a cost of 1 . But even if both sell their resources of 6 to the government, its reserves remain at 8 and allow it to maintain the fixed exchange rate. Thus, a trader who speculates receives a payoff of -1 , regardless of what the other one does, while one who holds gets 0 . Speculation thus is a strictly dominated strategy. The sole Nash equilibrium is the northwest corner: the currency peg necessarily survives.

The game shown in figure $2 b$ is the Low Reserve game. Committed reserves $R=6$, meaning that either trader alone can take out the currency peg. ${ }^{2}$ Suppose that in the event of giving up its peg the government devalues by 50 percent.

\footnotetext{
${ }^{2}$ At this point the model becomes uncomfortably impressionistic. As argued in detail by Obstfeld and Rogoff (1995), a level of foreign reserves in excess of the monetary basis is not necessary (nor, for that matter, sufficient) for indefinite maintenance of a currency peg. The assumption here that either player can unilaterally cause a collapse is simply a crude device for making collapse inevitable, as in Krugman's (1979) original model.
} 
Figure 2

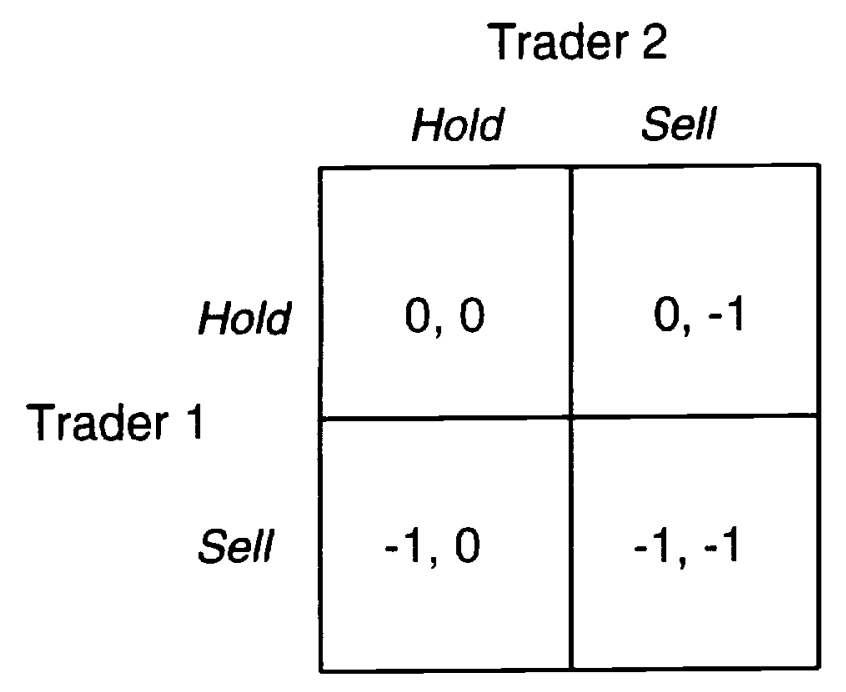

(a) High Reserve game $(R=20)$
Trader 2

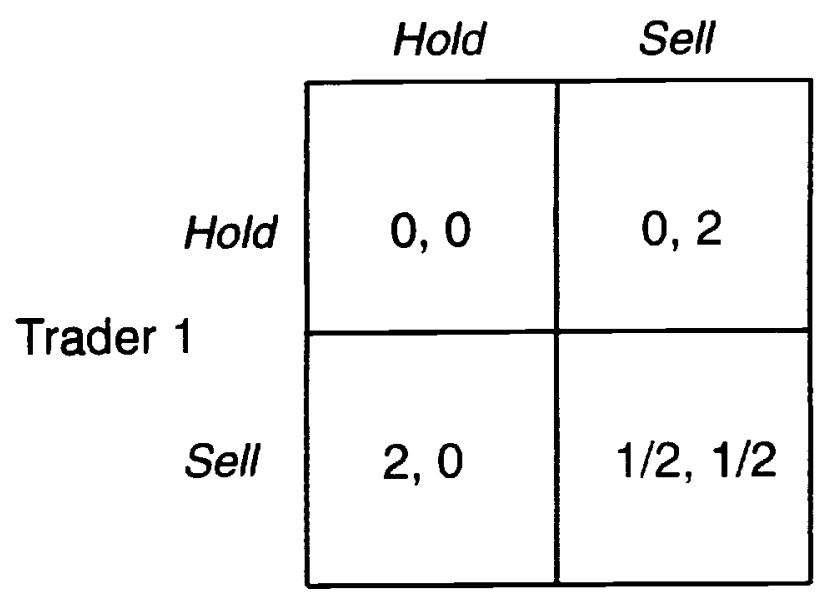

(b) Low Reserve game $(R=6)$

Trader 2

\begin{tabular}{c|c|c|}
\multicolumn{1}{c}{} & \multicolumn{1}{c}{ Hold } & \multicolumn{1}{c}{ Sell } \\
\cline { 2 - 3 } \multicolumn{1}{c}{ Hold } & 0,0 & $0,-1$ \\
\cline { 2 - 3 } Trader 1 & & \\
\cline { 2 - 3 } Sell & $-1,0$ & $3 / 2,3 / 2$ \\
\hline
\end{tabular}

(c) Intermediate Reserve game

$$
(R=10)
$$


A trader who has sold all his domestic currency has a capital gain (in domestic currency terms) of 3 , for a net gain of 2 after paying the transaction cost. If both traders sell, however, each gets half the government reserves and earns only $\frac{3}{2}-1=\frac{1}{2}$. Now, holding is a strictly dominated strategy; so the unique Nash equilibrium is the southwest corner, implying a collapse of the exchange rate.

The most interesting games is the Intermediate Reserve game of figure 2c. Here $R=10$, so neither trader alone can run the government's reserves although both can if they sell in concert. This generates the payoff structure shown. Either trader alone fails in an attack, bearing the cost -1 while the player who holds earns 0 . But if both attack, each gains $\frac{5}{2}-1=\frac{3}{2}$. There are now two Nash equilibria. In the first, shown in the southeast corner, both traders sell and the currency peg falls. But if neither trader believes the other will attack, the Nash equilibrium in the northwest corner results and the currency peg survives. In this game the attack equilibrium has a self-fulfilling element because the exchange rate collapses if attacked, but survives otherwise. The intermediate state of fundamentals (government reserves) makes a collapse possible, but not an economic necessity.

To use the terminology of Bulow, Geanakoplos, and Klemperer (1985) and Cooper and John (1988), speculative position-taking is subject to strategic com- 
plementarities in the Intermediate Reserve game, whereas in the Low Reserve game speculative actions are strategic substitutes. In figure $2 \mathrm{~b}$, the domestic currency will have to depreciate in any case: thus, greater profits for one speculator leaves fewer for others. In figure 2c, in contrast, no speculator makes profits unless others attack the exchange rate.

One fairly general prediction of this parable, noted in a different model by Jeanne (1995b), is that the state of fundamentals determines the existence and multiplicity of attack equilibria. In the simplest model of Krugman (1979), fundamentals are either consistent with long-run fixity of the exchange rate or are not. Here the same is true for extreme values of fundamentals, but there is also a large middle ground over which fundamentals are neither so strong as to make a successful attack impossible, nor so weak as to make it inevitable. In this case speculators may or may not coordinate on an attack equilibrium.

\section{An example based on unemployment}

This section turns to a fully-articulated model, based on Obstfeld $(1991,1994)$, in which the government's objectives are spelled out explicitly. In this model, multiple equilibria can be ranked by the degree of market skepticism in the current exchange rate, and the consequent worsening of employment conditional on the 
current parity's maintenance. ${ }^{3}$ Collapse may be a sure thing, as in the last section, but it need not be: different equilibria entail different probabilities of collapse. The model's basic framework is drawn from Barro and Gordon (1983), but assumes an open economy and identifies the price of foreign currency with the domestic price level.

The government minimizes the loss function

$$
\mathcal{L}=\left(y-y^{*}\right)^{2}+\beta \varepsilon^{2}+C(\varepsilon)
$$

where $y$ is output, $y^{*}$ the government's output target, and $\varepsilon \equiv e-e_{-1}$ the change in the exchange rate (the price of foreign currency). ${ }^{4}$ Output is determined by the expectations-augmented Phillips curve

$$
y=\bar{y}+\alpha\left(\varepsilon-\varepsilon^{e}\right)-u
$$

where $\bar{y}$ is the 'natural' output level, $\varepsilon^{e}$ is domestic price-setters' expectation of $\varepsilon$ based on lagged information, and $u$ is an i.i.d. mean-zero shock. The assumption

\footnotetext{
${ }^{3}$ Masson (1995) finds that an extended model along these lines helps to explain the experience of sterling after joining the ERM in October 1990. Masson's model, based on Drazen and Masson (1994), allows the public to learn about the strength of the government's aversion to inflation.

${ }^{4}$ Lower-case Roman letters are natural logarithms.
} 
$y^{*}>\bar{y}$ causes a dynamic inconsistency problem which, aside from being needed for multiple equilibria, provides a reason why a rational government might try to tie its hands by submitting to exchange-rate realignment costs. I take $\varepsilon^{e}$ to be time-invariant, which is the case in equilibrium given the model's assumptions. The government chooses the exchange rate $e$ after observing $u$ (unlike private price-setters), but any upward change in the rate (devaluation) leads to $C(\varepsilon)=\bar{c}$ in (3.1), whereas downward (revaluation) changes cost the government $C(\varepsilon)=\underline{c} .{ }^{5}$ Let us initially ignore the term $C(\varepsilon)$ in (3.1). Unencumbered thereby and with $\varepsilon^{e}$ predetermined, the government chooses

$$
\varepsilon=\frac{\alpha\left(y^{*}-\bar{y}+u\right)+\alpha^{2} \varepsilon^{e}}{\alpha^{2}+\beta}
$$

achieving an output level of

$$
y=\bar{y}+\frac{\alpha^{2}\left(y^{*}-\bar{y}\right)-\beta u-\alpha \beta \varepsilon^{e}}{\alpha^{2}+\beta}
$$

\footnotetext{
${ }^{5}$ The fixed cost of a parity change could be a political cost to reneging on a promise to fix the exchange rate (e.g., an ERM commitment). De Kock and Grilli (1993) show that similar results follow from private-sector trigger strategies that punish the government for exchange-rate changes.
} 
and a policy loss of

$$
\mathcal{L}^{\mathrm{FLEX}}=\frac{\beta}{\alpha^{2}+\beta}\left(y^{*}-\bar{y}+u+\alpha \varepsilon^{e}\right)^{2}
$$

With no option whatsoever to change the exchange rate, the loss instead is

$$
\mathcal{L}^{\mathrm{FIX}}=\left(y^{*}-\bar{y}+u+\alpha \varepsilon^{e}\right)^{2}
$$

Now reintroduce the fixed costs $C(\varepsilon)$. In their presence, (3.3) is operative only when $u$ is so high that $\mathcal{L}^{\text {FLEX }}+\bar{c}<\mathcal{L}^{\text {FIX }}$ or so low that $\mathcal{L}^{\text {FLEX }}+\underline{c}<\mathcal{L}^{\text {FIX }}$. Devaluation thus occurs for $u>\bar{u}$, and revaluation for $u<\underline{u}$, where

$$
\bar{u}=\frac{1}{\alpha} \sqrt{\bar{c}\left(\alpha^{2}+\beta\right)}-y^{*}+\bar{y}-\alpha \varepsilon^{e}, \underline{u}=-\frac{1}{\alpha} \sqrt{\underline{c}\left(\alpha^{2}+\beta\right)}-y^{*}+\bar{y}-\alpha \varepsilon^{e} .
$$

Let $u$ be uniformly distributed on $[-\mu, \mu]$. The rational expectation of next period's $\varepsilon$, given price setters' expectation $\varepsilon^{e}$, is

$$
\mathrm{E} \varepsilon=\mathrm{E}(\varepsilon \mid u<\underline{u}) \operatorname{Pr}(u<\underline{u})+\mathrm{E}(\varepsilon \mid u>\bar{u}) \operatorname{Pr}(u>\bar{u})
$$


or, by direct computation using (3.3),

$$
\mathrm{E} \varepsilon=\frac{\alpha}{\alpha^{2}+\beta}\left[\left(1-\frac{\bar{u}-\underline{u}}{2 \mu}\right)\left(y^{*}-\bar{y}+\alpha \varepsilon^{e}\right)-\frac{\bar{u}^{2}-\underline{u}^{2}}{4 \mu}\right] .
$$

In full equilibrium $E \varepsilon=\varepsilon^{e}$. To find fixed points of (3.4), figure 3 graphs it together with a 450 line. Let $-i^{*}$ denote the minimum possible level of $\varepsilon^{e},{ }^{6}$ and assume that $\underline{c}$ and $\bar{c}$ are small enough that at $\varepsilon^{e}=-i^{*}, \underline{u}>-\mu$ and $\bar{u}<\mu$. Since $\mathrm{d} \bar{u} / \mathrm{d} \varepsilon^{e}=\mathrm{d} \underline{u} / \mathrm{d} \varepsilon^{e}=-\alpha$ if $\underline{u}>-\mu$ but $\mathrm{d} \underline{u} / \mathrm{d} \varepsilon^{e}=0$ once $\underline{u}=-\mu$ and $\mathrm{d} \bar{u} / \mathrm{d} \varepsilon^{e}=0$ once $\bar{u}=-\mu$, the slope of $(3.4)$ is

$$
\frac{\mathrm{dE} \varepsilon}{\mathrm{d} \varepsilon^{e}}=\left\{\begin{array}{lc}
\frac{\alpha^{2}}{\alpha^{2}+\beta} & (\text { for } \underline{u}>-\mu) \\
\frac{\alpha}{\alpha^{2}+\beta}\left[\frac{\alpha}{2}+\frac{\alpha}{2 \mu}\left(y^{*}-\bar{y}+\alpha \varepsilon^{e}\right)\right] & (\text { for } \underline{u}=-\mu) \\
\frac{\alpha^{2}}{\alpha^{2}+\beta} & (\text { for } \bar{u}=-\mu)
\end{array}\right.
$$

Once $\varepsilon^{e}$ has risen high enough that $\bar{u}$ is stuck at $-\mu$, the government's reaction function is simply (3.3) and depreciation expectations are the same as under a freely flexible exchange rate.

Figure 3 shows how there can be three equilibrium expected depreciation rates, $\varepsilon_{1}, \varepsilon_{2}$, and $\varepsilon_{3}$, corresponding to three different devaluation probabilities

\footnotetext{
${ }^{6}$ This is the level at which, given interest parity, the nominal domestic interest rate is zero.
} 


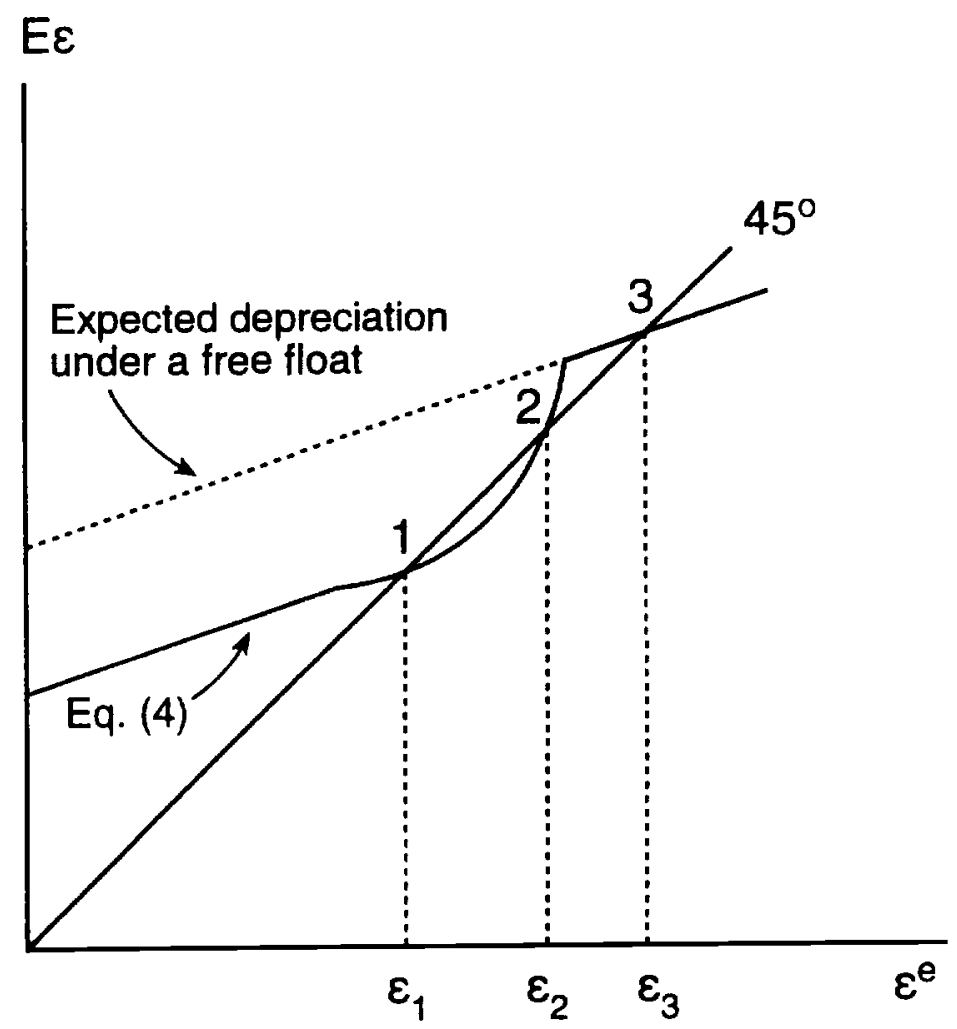

Figure 3 
and realignment magnitudes conditional on devaluation. Equilibrium 3, in which $\bar{u}=-\mu$, must actually entail the same mean depreciation rate $\mathrm{E} \varepsilon=(\alpha / \beta)\left(y^{*}-\bar{y}\right)$ as the freely flexible exchange-rate equilibrium, corresponding to the case in Barro and Gordon (1983). Figure 3 shows clearly that this last equilibrium has to exist, even when $\bar{c}>0$, if there are to be multiplicities at all. The formal parameter restriction required is

$$
\frac{\alpha^{2}+\beta}{\beta}\left(y^{*}-\bar{y}\right)-\mu \geq \frac{1}{\alpha} \sqrt{\bar{c}\left(\alpha^{2}+\beta\right)}
$$

which is more likely to hold if the devaluation cost $\bar{c}$ is low, the slope $\alpha$ of the Phillips curve is high, inflation aversion $\beta$ is low, and the credibility distortion $y^{*}-\bar{y}$ is big. This condition means that if markets expect the floating exchangerate average depreciation rate it will materialize, the fixed cost of devaluation notwithstanding. ${ }^{7}$

The government is powerless (in the model) to enforce its preferred equilibrium should market expectations coalesce around an inferior one. Further, some seemingly minor random event (a sunspot) could shift the exchange rate from a

\footnotetext{
${ }^{7}$ With distributions for $u$ more complicated than the uniform, there can be multiple equilibria even when devaluation costs rule out the Barro-Gordon floating-rate equilibrium; see Obstfeld (1991). The discussion of a numerical uniformly-distributed example in Obstfeld (1994) restricts itself to searches for switch points $\bar{u}$ in the interior of $[-\mu, \mu]$ and neglects to point out that $\bar{u}=-\mu$ is a bona fide equilibrium too.
} 
position where it is vulnerable to only very bad $u$ realizations to one where output is so low absent devaluation that even moderate shocks will induce the authorities to realign. The government could also be forced into an immediate effective float.

Just as in the last section, the strength of 'fundamentals', as reflected in the government's tastes and the economy's structure, affects the multiplicity of equilibria. One can show, for example, that a fall in the natural output level $\bar{y}$ shifts the vertical intercept of eq. (3.4) upward. Thus, as $\bar{y}$ falls from $y^{*}$, the corresponding expectations schedule shifts from a single low-inflation intersection with the $45 \circ$ line, to three, and back to a unique equilibrium in which devaluation is a probability 1 event.

\section{Alternative mechanisms and early evidence}

The last section's example gives the flavor of recent work on self-fulfilling crises, but covers only one of many mechanisms that have been discussed. Many of these mechanisms hinge on the effects of higher nominal interest rates, and it is precisely because a self-fulling crisis may result from a sunspot with low ex ante probability that (in a world of incomplete markets) the effects can be so devastating.

Public debt. This mechanism was especially evident in Italy's 1992 predicament. Highly indebted governments with mostly short-term or floating-rate nom- 
inal debts will find their fiscal burden increased sharply if market expectations of depreciation drive up domestic interest rates. This may induce devaluation of domestic-currency debt. Interestingly, the literature [e.g., Obstfeld (1994)] has shown that partial indexation of the debt to a foreign currency can worsen a crisis if one occurs, a factor clearly at work in the 1994-95 Mexican experience.

Banks. Many financial intermediaries come under pressures when market interest rates unexpectedly rise. The government's desire to sidestep a costly bailout at public expense may move it toward a quick devaluation. Similarly, the prospect that the central bank will have to exercise its lender of last resort function by expanding the monetary base exposes the government to a potential pressure on its foreign reserves far beyond the pre-crisis high-powered money supply [e.g., Velasco (1987)].

Income distribution. Unexpected interest rate changes redistribute income domestically in ways that governments may find undesirable. The rapid impact of market on mortgage interest rates was a powerful factor in Britain's September 1992 withdrawal from the ERM.

Real interest rates. The last section's analysis allowed for an effect of reduced competitiveness on output, but not for real interest-rate effects. With sticky domestic prices, however, hikes in nominal interest rates imply hikes in short 
term real rates, and these may generate self-fulfilling devaluation pressures [e.g., Bensaid and Jeanne (1994), Ozkan and Sutherland (1995)].

Spillovers and contagion effects. A speculative attack forcing the devaluation of one country's currency may reduce a trading partner's competitiveness sufficiently to make its exchange rate, too, subject to crisis (with or without self-fulfilling features). International spillovers of this type are highlighted by Andersen (1994), Buiter, Corsetti, and Pesenti (1995), and Gerlach and Smets (1994). In addition, country-specific sunspots may be internationally correlated. In the Latin American context, Calvo and Reinhart (1995) present evidence of regional contagion effects on capital inflows.

Empirical work on self-fulfilling crises is suggestive but still at an early stage. Eichengreen, Rose, and Wyplosz $(1995,1996)$ examine a large number of attack episodes, including ones in which the exchange rate's defense succeeded, along with realignments. Their finding that speculative attack episodes differ widely among themselves in displaying significant pre-crisis changes in such variables as competitiveness, fiscal deficits, and unemployment suggests it may be hard to explain crises without postulating that at least some involve self-fulfilling elements. ${ }^{8}$

\footnotetext{
${ }^{8}$ Martinez Peria (1995) finds more uniformity in a logit analysis of 1957-88 Latin American devaluation episodes.
} 
The finding of Rose and Svensson (1994) that ERM credibility did not deteriorate markedly until August 1992 likewise suggests that most of the system's rates were not viewed as unsustainable by markets until the 1992 crisis actually erupted. Jeanne (1995b) develops a structural estimation strategy whose result indicates a strong self-fulfilling aspect of France's 1992-93 exchange-market travails. 


\section{References}

[1] Andersen, T.M., 1994, Shocks and the viability of a fixed exchange rate commitment, Discussion paper no. 969 (CEPR, London).

[2] Barro, R.J. and D.B. Gordon, 1983, A positive theory of monetary policy in a natural rate model, Journal of Political Economy 91, 589-610.

[3] Bensaid, B. and O. Jeanne, 1994, The instability of fixed exchange rate systems when raising the nominal interest rate is costly, Discussion paper no. 190 (LSE Financial Markets Group, London).

[4] Buiter, W.H., G. Corsetti, and P.A. Pesenti, 1995, A center-periphery model of monetary coordination and exchange rate crises, Working paper no. 5140 (NBER, Cambridge, MA).

[5] Bulow, J.I., J.D. Geanakoplos, and P.D. Klemperer, 1985, Multimarket oligopoly: Strategic substitutes and complements, Journal of Political Economy $93,488-511$.

[6] Calvo, G.A., 1995, Varieties of capital-market crises, Working paper (University of Maryland, College Park, MD). 
[7] Calvo, S. and C. Reinhart, 1995, Capital flows to Latin America: Is there evidence of contagion effects? Working paper (International Monetary Fund, Washington).

[8] Chen, Z., 1995, Speculative market structure and the collapse of an exchange rate mechanism, Discussion paper no. 1164 (CEPR, London).

[9] Cooper, R. and A. John, 1988, Coordinating coordination failures in Keynesian models, Quarterly Journal of Economics 103, 441-463.

[10] De Kock, G. and V. Grilli, 1993, Fiscal policies and the choice of exchange rate regime, Economic Journal 103, 347-358.

[11] Drazen, A. and P.R. Masson, 1994, Credibility of policies versus credibility of policymakers, Quarterly Journal of Economics 109, 735-754.

[12] Eichengreen, B., A.K. Rose, and C. Wyplosz, 1995, Exchange market mayhem: The antecedents and aftermath of speculative attacks, Economic Policy 21 , forthcoming.

[13] Eichengreen, B., A.K. Rose, and C. Wyplosz, 1996, Speculative attacks on pegged exchange rates: An empirical exploration with special reference to the European Monetary System, in: M.B. Canzoneri, P.R. Masson, and V.U. 
Grilli, eds., Transatlantic economic issues (Cambridge University Press, Cambridge, UK).

[14] Eichengreen, B. and C. Wyplosz, 1993, The unstable EMS, Brookings Papers on Economic Activity 1, 51-143.

[15] Flood, R.P. and P.M. Garber, 1984, Collapsing exchange-rate regimes: Some linear examples, Journal of International Economics 17, 1-13.

[16] Gerlach, S. and F. Smets, 1994, Contagious speculative attacks, Discussion paper no 1055 (CEPR, London).

[17] Jeanne, O., 1995a, Models of currency crises: A tentative synthesis, Working paper (ENPC-CERAS, Paris).

[18] Jeanne, O., 1995b, Are currency crises caused by the fundamentals or by self-fulfilling speculation? A test, Working paper (ENPC-CERAS, Paris).

[19] Krugman, P., 1979, A model of balance-of-payments crises, Journal of Money, Credit and Banking 11, 311-325.

[20] Martinez Peria, M.S., 1995, Understanding devaluations in Latin America: A 'bad fundamentals' approach, Working Paper (University of California, Berkeley, CA). 
[21] Masson, P.R., 1995, Gaining and losing ERM credibility: The case of the United Kingdom, Economic Journal 105, 571-582.

[22] Obstfeld, M., 1991, Destabilizing effects of exchange rate escape clauses, Working paper no. 3603 (NBER, Cambridge, MA).

[23] Obstfeld, M., 1994, The logic of currency crises, Cahiers Économiques et Monétaires (Banque de France) 43, 189-213.

[24] Obstfeld, M. and K. Rogoff, 1995, The mirage of fixed exchange rates, Journal of Economic Perspectives 9, forthcoming.

[25] Ozkan, F.G. and A. Sutherland, 1995, Policy measures to avoid a currency crisis, Economic Journal 105, 510-519.

[26] Rose, A.K. and L.E.O. Svensson, 1994, European exchange rate credibility before the fall, European Economic Review 38, 1185-1216.

[27] Velasco, A., 1987, Financial crises and balance of payments crises, Journal of Development Economics 27, 263-283. 